International Review of Research in Open and Distributed Learning Volume 19, Number 2

April - 2018

\title{
Empirical Analysis on Factors Impacting on Intention to Use M-learning in Basic Education in Egypt
}

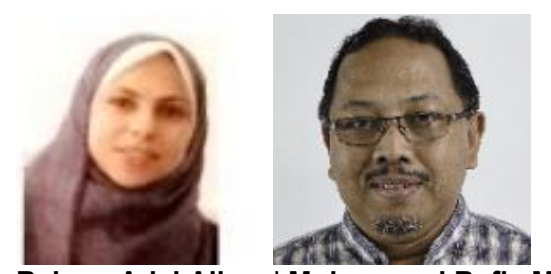

Reham Adel Ali and Muhammad Rafie Mohd Arshad

Universiti Sains Malaysia, Penang, Malaysia

\begin{abstract}
It is apparent that m-learning will continuously have a massive role in terms of development in teaching and learning methods for education. Student's intention to use this technology is the main factor that eventually leads to a success in implementing m-learning. The objectives of this particular research are to come up with the development and examination towards a research model to uncover the factors that have important effects on the intention to use mobile learning for basic education in Egypt. A research model was developed through extending the unified theory of acceptance and use of technology (UTAUT) by incorporating two additional factors namely; learners' autonomy (LA) and content quality design (CQD). A quantitative approach based on cross-sectional survey was used to collect data from 386 respondents.. The methodology used in this study was a Partial Least Squares (PLS) that was expected to test the model empirically. The results showcased that learners' autonomy (LA), performance expectancy (PE), facilitating conditions (FC), and social influence (SI) are significant in relation to behavioural intention (BI) to use mlearning while effort expectancy (EE) did not show the impact on intention to use mobile learning. The research also found that content quality design (CQD) affects significantly on performance expectancy (PE) and effort expectancy (EE). The possible development in future research and the limitations of the findings are also discussed later in this paper.
\end{abstract}

Keywords: content quality design, education, Egypt, intention to use, learners' autonomy, m-learning, mobile learning, unified theory of acceptance and use of technology (UTAUT), schools, students 


\section{Introduction}

With the continued development in the field of mobile technology, a new paradigm in education has been appeared called mobile learning or m-learning. According to Hwang and Tsai (2011), m-learning is described as using mobile technologies to facilitate learning. Generally, m-learning can be viewed as any form of learning that takes place when mediated through a mobile device (Winters, 2007). Technology is not necessarily the most important factor that affects m-learning; according to Freitas and Schlemmer (2013), the perception of mobility is the most crucial factor. One of the most popular forms of m-learning in education is the usage of the applications (apps) of m-learning. Apps can be defined as a small program with accessibility via a wireless network that can be downloaded onto smartphones or tablets. The utilization of apps will provide accessibility to learning resources, interesting activities (that include interactive educational games and quizzes), and it also allows sharing among learners when it comes to educational information.

There are so many advantages that m-learning may offer its users, including interactive learning activities, self-managing learning, corporate learning, personalized learning, and an effective methodology of sending and receiving knowledge (Bidin \& Ziden, 2013; Jeong \& Hong, 2013; Martin \& Ertzberger, 2013; Viberg \& Grönlund, 2013). Mobility is deemed as the strongest feature of mobile learning in comparison with the traditional education (Coursaris \& Hassanein, 2002; Liu, 2011) as it allows students to have access and exchange information wherever and whenever they need to. This will help solve the problems regarding students' transition to access learning resources. Apart from that, it is also believed that m-learning has the ability to manage collaborative learning via interaction. The presence of mobile devices helps achieve interaction and improves the accessibility of learning materials (Liaw, Hatala, \& Huang, 2010). SMS, WhatsApp, and Viber are some of the communication platforms that allows for interaction. Three possible interaction forms of m-learning include, interaction among the students themselves, between students and educators, or between students and content (Alshalabi \& Elleithy, 2012; Dyson, Litchfield, Raban, \& Tyler, 2009). With the help of this interaction, it is possible for the students to exchange and share information, knowledge, and ideas (Kuo, Walker, Schroder, \& Belland, 2014) and this allows the learning process to become a lot more attractive. The use of edutainment applications, such as educational games and e-books, through mobile technology, allows the learning process to be more enjoyable and interesting (Ali \& Arshad, 2016). Apart from that, m-learning also makes situated learning feature available. As the students carry their mobile devices wherever they go, it is possible for them to capture their own materials using cameras for pictures and videos, eventually exchange and share them with other students and lecturers (Ali \& Arshad, 2016). M-learning improves responsible behaviour and autonomous learning, and this allows the students to become the focal point of the learning process and manage their learning as well. Based on that, it can be concluded that m-learning is a complementary activity to the traditional learning.

Galal (2016) stated that currently, the educational system in Egypt is in a critical state. Based on the "quality of the education system" index in the World Economic Forum's 2015-2016 Global Competitiveness Report, the country only ranked 139th out of 140 countries. Some of the reasons why the rank is so low are the limited flexibility of the curriculum, being highly dependent on rote memorization instead of scientific research, overcrowded classroom, and low availability of classrooms, lack of laboratories, and low-quality 
teachers. On the other hand, some students leave schools to avoid transportation costs. . In addition, the poor teaching quality and lack of student participation negatively effects knowledge transfer as well.

Sureephong, Sirichai, and Winya (2015) also stated that m-learning is a solution tool that allows changes in the education system, transforming the traditional teaching into modern teaching. To a certain extent, mobile learning also represents a way to solve numerous educational issues (West, 2013). In accordance, m-learning has an objective to be a learning tool with novelty that may solve the issues the Egyptian education system currently suffers from.

In Egypt, children between eight and 18-years-old download or use entertainment apps more than education and learning apps. A study by GSM Association and NTT DOCOMO (2014) shows it is also accordingly imperative to identify the factors that affect the level of students' intention to use mobile technology in learning instead of playing games and browsing entertainment. The objectives of this particular research are to come up with the development and examination towards a research model to uncover the factors that have important effects on the intention to use mobile learning for basic education in Egypt. Finally, the paper tries to shed light on the basic education context in Egypt where most studies are done on university education.

\section{Literature Review}

In the world of information systems, there are numerous models developed to analyse individuals' acceptance and intention to adopt new technologies. Davis (1989) attempted to figure out the reasons of people's acceptance and rejection of information technology. The technology acceptance model (TAM) is the most highly adopted model in the field of technology (Davis, 1989). TAM has the ability to provide a theoretical basis that helps explain the impact of external variables (i.e., objective system design characteristics, training, computer self-efficacy) on internal beliefs, attitude toward use, behavioural intentions, and actual system use (Ibrahim \& Jaafar, 2011). The unified theory of acceptance and use of technology (UTAUT) is another popularly used and also one of the most recently developed model in regard to information technology acceptance. Venkatesh, Morris, Davis, and Davis (2003) proposed this theory and attempted to channel and empirically compare elements from numerous technology acceptance models in technology acceptance.

In UTAUT, there are four determinants of IT user behaviour and four moderators that are able to moderate the effect of the four determinants on the behaviour intention and user behaviour. UTAUT develops a theory that says performance expectancy, effort expectancy, social influence, and facilitating conditions are direct determinants of behaviour intention or user behavior. The fact mentioned above allows great improvement to the explanatory power of the model. Apart from that, the moderating variables (gender, age, experience, and voluntariness of use) are very crucial when it comes to understanding the characteristics of different user groups (see Figure 1).

UTAUT is able to explain around 70\% of the variance in the intention Venkatesh et al. (2003) stated. Also, it was also indicated that UTAUT has shown the superiority to outperform the previous models (Venkatesh et al., 2003). Additionally, the model can act a beneficial tool for managers that is able to assess the success of the new technology (Ibrahim \& Jaafar, 2011). 
Many studies discussed the factors that have an impact on students' intention to use m-learning. Table 1 showcases some of the latest studies on intention to use m-learning employing UTAUT. The results show that student's intention to use m-learning is the main key to developing a successful m-learning system. Therefore, it is believed that there will be a need to investigate the factors that affect their intention to use $\mathrm{m}$-learning and to solve all issues that may hinder the success of the factors.

Table 1

Recent Studies on M-learning Intention to Use

\begin{tabular}{|c|c|c|c|}
\hline Author & IS & Sample & Results \\
\hline $\begin{array}{l}\text { 1. Kuciapski } \\
\text { (2016) }\end{array}$ & M-learning & \begin{tabular}{l}
\multicolumn{1}{c}{370} \\
university \\
students
\end{tabular} & $\begin{array}{l}\text { This research argued that in contrast to UTAUT } \\
\text { model, it is believed that facilitating condition does not have } \\
\text { to be necessarily connected with use behaviour. Moreover, a } \\
\text { correlation between other UTAUT variables as effort } \\
\text { expectancy and performance expectancy has been }\end{array}$ \\
\hline $\begin{array}{l}\text { 2. Badwelan, } \\
\text { Drew, and } \\
\text { Bahaddad } \\
\text { (2016) }\end{array}$ & M-learning & \begin{tabular}{l}
\multicolumn{1}{c}{400} \\
university \\
students
\end{tabular} & $\begin{array}{l}\text { Performance expectancy, effort expectancy, } \\
\text { lecturers' influence, personal innovativeness, and self- } \\
\text { management have shown significant effects on behavioural } \\
\text { intention. }\end{array}$ \\
\hline $\begin{array}{l}\text { 3. Jawad and } \\
\text { Hassan } \\
\text { (2015) }\end{array}$ & M-learning & $\begin{array}{l}159 \\
\text { university } \\
\text { students } \\
\text { and } \\
\text { lectures }\end{array}$ & $\begin{array}{l}\text { The research suggested that the strongest indicator of } \\
\text { the behavioural intention is performance expectancy. It was } \\
\text { then followed by self-management learning, effort expectancy, } \\
\text { perceived playfulness, and social influence. On the use } \\
\text { behaviour aspect, the strongest indicator is the behavioural } \\
\text { intention and the second strongest factor is facilitating } \\
\text { condition. }\end{array}$ \\
\hline $\begin{array}{l}\text { 4. Ng, Ibrahim, } \\
\text { Ahmad, and } \\
\text { Ng (2015) }\end{array}$ & M-learning & $\begin{array}{l}\text { 400 } \\
\text { university } \\
\text { students }\end{array}$ & $\begin{array}{l}\text { The author decided to remove the moderators of the } \\
\text { UTAUT, facilitating condition, and extended it with self- } \\
\text { management of learning and perceived playfulness. The } \\
\text { results showcased that performance expectancy and self- } \\
\text { management of learning are strongly related to behavioural } \\
\text { intention to use m-learning while effort expectancy, social } \\
\text { influence, and perceived playfulness do not necessarily } \\
\text { indicate a significant relationship with Intention to use m- } \\
\text { learning. }\end{array}$ \\
\hline 5. $\quad$ Bere (2014) & M-learning & $\begin{array}{l}196 \\
\text { university } \\
\text { students }\end{array}$ & $\begin{array}{l}\text { This study identified that performance expectancy } \\
\text { (PE), effort expectancy (EE), social influence (SI), student- } \\
\text { centric learning and hedonic motivation are the determinants } \\
\text { of behavioural intention and use of mobile learning using } \\
\text { WhatsApp. PE, SI, and hedonic motivation is later moderated } \\
\text { by marital status. }\end{array}$ \\
\hline
\end{tabular}




\begin{tabular}{|l|l|l|l|}
\hline $\begin{array}{l}\text { 6. } \begin{array}{l}\text { Abu-Al-Aish } \\
\text { and Love } \\
\text { (2013) }\end{array} \\
\end{array}$ & $\begin{array}{l}174 \\
\text { university } \\
\text { students }\end{array}$ & $\begin{array}{l}\text { M-learning } \\
\text { that performance expectancy, effort expectancy, the influence } \\
\text { of lecturers, quality of service, and personal innovativeness } \\
\text { have a significant impact on behavioural intention to use m- } \\
\text { learning. It was also found that prior experience of mobile } \\
\text { devices was able to moderate the effect of these constructs on } \\
\text { behavioural intention. }\end{array}$ \\
\hline
\end{tabular}

\section{Research Model}

UTAUT is used in this study as a basic platform and some modifications are also added to the traditional UTAUT model. The reason of doing so is to predict the actual behaviour in the most accurate manner (Davis, 1989; Sheppard, Hartwick, \& Warshaw, 1988; Venkatesh \& Davis, 2000). In addition, the dependent variable of the intention to use of m-learning was the behavioural intention. Apart from that, the actual use or the construct of user behaviour was eliminated. Furthermore, this study will evaluate the intention to use m-learning in regard to completely voluntary usage and by employing a population of students of the same age and same level of experience. Therefore, it was decided that voluntariness of usage, age, and experience should be eliminated as moderators. Furthermore, this study is not interested to test the gender as a moderator. This research combined two additional constructs into UTAUT in order to investigate the factors that might affect student intention to use m-learning in Egypt: Learners' autonomy and content quality design.

\section{Research Dimensions and Hypothesis}

\section{Performance Expectancy (PE)}

According to Venkatesh et al. (2003), performance expectancy and effort expectancy in UTAUT are similar to perceived usefulness and perceived ease of use in TAM. Performance expectancy (perceived usefulness) can be described as the level to which an individual perceives using the new technology will help them achieve a benefit in regard to the performance of a task (Venkatesh et al., 2003). In most cases of m-learning studies, it is suggested that performance expectancy (PE) affects an individual's behavioural intention to utilize m-learning in a positive way (Abu-Al-Aish \& Love, 2013; Chang, 2013; Jambulingam, 2013; Nassuora, 2012). Involving concept of PE to the study will help investigate the intention of the students to use m-learning. They will have trust in m-learning as they believe the technology has the ability to help improve their performance. From the argument mentioned above, the following hypothesis is postulated:

H1: Performance expectancy has a positive impact on the intention of students to use m-learning.

\section{Effort Expectancy (EE)}

Effort expectancy (perceived ease of use) can be described as the level to which an individual perceives the new technology will be easy to use (Venkatesh et al., 2003). Many studies suggested there is a huge impact of the concept of effort expectancy on the intention of users to apply the m-learning technology (Abu-AlAish \& Love, 2013; Al-Hujran, Al-Lozi, \& Al-Debei, 2014; Chung, Chen, \& Kuo, 2015; Jairak, 
Praneetpolgrang, \& Mekhabunchakij, 2009; Nassuora, 2012; Wang, Wu, \& Wang, 2009). To adapt the effort expectancy, an evaluation of the students' intention to use m-learning showcases the students will utilize m-learning if they perceive that this new technology is user-friendly. Therefore, the following hypothesis is formed:

H2: Effort expectancy has a positive impact on the intention of students to use m-learning.

\section{Social Influence (SI)}

Social influence (SI), in regard to new technology and social influence, can be described as the level to which an individual perceives the new technology will be important according to others' belief (Venkatesh et al., 2003). Numerous studies identified experience has a moderating effect on the social influence on a user's behavioural intention to use m-learning (Venkatesh et al., 2003). Several studies in the related literature claimed social influence has a significant impact on a user's behavioural intention to use m- learning (AbuAl-Aish \& Love, 2013; Al-Hujran et al., 2014; Jairak et al., 2009; Wang et al., 2009). For the young students, it is believed that their parents, their friends, and their teachers are the individuals who encourage them to use m-learning, especially in the significance of educative mobile technology usage (Liu, 2011). Therefore, it is imperative to incorporate social influence in this research to investigate the opinions of parents and teachers in regard to intention to use m-learning technology. Based on the discussion above, the following hypothesis is proposed:

H3: Social influence has a positive impact on the intention of students to use m-learning.

\section{Facilitating Conditions (FC)}

A facilitating condition (FC) can be described as the level to which an individual that the technical aspects and existing organization infrastructure will be able to support the presence of the new technology (Venkatesh et al., 2003). Many relevant literatures investigating mobile technology showcased that a facilitating condition will have a positive effect on an individual's behaviour intention (Attalla, El-Sherbiny, Mokbel, El-Moursy, \& Abdel-Wahab, 2012; Iqbal \& Qureshi, 2012; Jairak et al., 2009).

An important necessity for young students who would like to use m-learning to own a mobile device as it will encourage the process of m-learning (Liu, 2011). In accordance, the support from the parents also plays important role in the success of m-learning implementation in schools. Furthermore, with the permission of their parents, students can also continue interacting with the system by using mobile devices at home (Liu, 2011). Therefore, it is important to incorporate this concept to m-learning. This showcases that the students have the perception of the availability of mobile devices. With the presence of parental support, m-learning will easily let them access to designated infrastructure and learning materials. This will also help facilitate interaction with their teachers and other students. Based on argument stated above, the following hypothesis is postulated:

H4: Facilitating condition has a positive impact on the intention of students to use m-learning.

\section{Learners' Autonomy (LA)}

Researchers suggested that in order to have a better experience in learning, it is imperative that the learners are actively involved in the system (Bidin \& Ziden, 2013). Taking a more active role allows an increased 
likelihood that students be more interested in taking part in learning experience the encouragement is highly present (Selfe, 1999; Watts, 1997). M-learning provides a chance for students to have major contributions in the learning process by getting involved and taking an active role right from the start and by ensuring they understand the goal at the point of evaluation (Makoe, 2010). A mobile device can be carried away all the times and it is possible for the users to take more control.

Learning autonomy, in the context of m-learning, means the ability of the students to have adequate and enough responsibility for their learning process via mobile devices (Yeap, Ramayah, \& Soto-Acosta, 2016). A study conducted by Liaw, Huang, and Chen (2007) on instructor and learners' attitude towards elearning, identified that the effective learning autonomy is a huge aspect in the acceptance of e-learning system. Thus, the following hypothesis is constructed:

H5: Learning autonomy has a positive impact on the intention of students to use m-learning.

\section{Content Quality Design (CQD)}

One of the reasons the students are not interested in mobile learning applications is the lack of content quality (Liu, 2011). Most of the systems only offer them with learning materials that are not attractive and enjoyable enough to them. Additionally, mobile devices involve the presence of unique features such as small screen size that make previous e-learning materials for personal computer (desk computer) usage are no longer suitable to be applied in these devices. Thus, it is crucial that we consider mobile application content quality as a factor in this study.

The content quality design is associated with the type and format of learning content (Lee \& Kozar, 2006). The format of learning content is related to the students' perception on how the learning material content is showcased by the system. Liu, Han, and Li (2010) claimed that the type of learning content plays a huge role for learners. In addition, the study of Almaiah, Jalil, and Man, 2016 on the effects of quality features on mobile learning acceptance, found that the content quality design is a significant aspect in regard to mobile learning acceptance. Therefore, the following hypotheses are postulated:

H6: Content quality design has a positive impact on Performance Expectancy.

H7: Content quality design has a positive impact on Effort Expectancy.

\section{Methodology}

The questionnaire consisted of 24 items adapted from Almaiah et al. (2016), Venkatesh and Davis (2000), and Yeap et al. (2016) for measuring seven constructs and was conducted on public preparatory schools in Cairo, Egypt. The listing of all public preparatory schools' names in Cairo and the list of the names of all students in each class are known. Additionally, there are two types of public schools in Egypt, Arabic schools and language schools; therefore, this study used a stratified sampling technique to collect the data. The sample size determined from the population was based on the Krejcie and Morgan Table (Krejcie \& Morgan, 1970). The public schools in Cairo were divided into two clusters according to the medium of study-368 Arabic schools and 216 language schools-then a random selection was conducted from these clusters. Next, 
based on the number of all students in each grade and the sample size of 384 , we defined the participated students in each school. A total of 400 questionnaires were distributed, with a total of 386 questionnaires completed. Paper-based survey questionnaires were used to collect the data. Before the students completed the questionnaire, the researcher provided them with a short description of the research purposes and what m-learning is all about. The characteristics of the participants are displayed in Table 2.

Table 2

Profile of Respondents

\begin{tabular}{|l|c|c|}
\hline \multicolumn{1}{|c|}{ Profile } & Frequency & Percentage \\
\hline $\begin{array}{l}\text { Gender } \\
\text { Male } \\
\text { Female }\end{array}$ & 235 & 90.9 \\
\hline Age & 151 & 39.1 \\
$\quad 15-18$ & 255 & 66.0 \\
\hline $\begin{array}{l}\text { Own Smartphone } \\
\text { Own tablet } \\
\text { Own both }\end{array}$ & 131 & 34.0 \\
\hline $\begin{array}{l}\text { Do you use m-learning in your } \\
\text { studies? }\end{array}$ & 177 & 45.9 \\
Yes & 114 & 24.6 \\
No & & 29.5 \\
& & \\
\hline
\end{tabular}

\section{Data Analysis and Results}

To analyze the research model, we utilize the Partial Least Squares (PLS) analysis technique using the SmartPLS 3.0 software (Ringle, Wende, \& Becker, 2015). Dependent on the recommended two-stage analytical procedures by Anderson and Gerbing (1988), the measurement model (validity and reliability of the measures) was investigated and then followed by an evaluation of the structural model (testing the hypothesized relationships; Alzahrani, Stahl, \& Prior, 2012; Hair, Sarstedt, Hopkins, \& G. Kuppelwieser, 2014; Ramayah, Lee, \& In, 2011). A bootstrapping method was used to check the significance of the loadings and the path coefficients (Hair et al., 2014).

\section{Measurement Model Evaluation}

We initially assessed convergent validity according to the suggestions by Hair et al. (2014) by investigating the loadings, average variance extracted (AVE), and composite reliability (CR). Hair et al. (2014) suggested that the loadings should be $>0.70, \mathrm{CR}>0.7$, and AVE $>0.5$. As shown in Table 3, the AVE was greater than 0.5 and the CR was greater than 0.7. All loadings were above the cut-off value except for FC1, PE1, and SI1 which was respectively $0.695,0.432$, and 0.673 
Table 3

Results for the Measurement Model

\begin{tabular}{|c|c|c|c|c|}
\hline Constructs & Items & Loading & AVE & $\mathrm{CR}$ \\
\hline \multicolumn{5}{|c|}{ Behavioral intention } \\
\hline & BI1 & 0.715 & 0.62 & 0.83 \\
\hline & $\mathrm{BI} 2$ & 0.845 & & \\
\hline & $\mathrm{BI} 3$ & 0.798 & & \\
\hline \multicolumn{5}{|c|}{$\begin{array}{c}\text { Content quality } \\
\text { design }\end{array}$} \\
\hline & CQD1 & 0.727 & 0.539 & 0.824 \\
\hline & CQD2 & 0.731 & & \\
\hline & CQD3 & 0.72 & & \\
\hline & CQD4 & 0.758 & & \\
\hline \multicolumn{5}{|c|}{ Effort expectancy } \\
\hline & EE1 & 0.765 & 0.587 & 0.81 \\
\hline & EE2 & 0.797 & & \\
\hline & EE3 & 0.735 & & \\
\hline \multicolumn{5}{|c|}{ Facilitating conditions } \\
\hline & FC2 & 0.831 & 0.72 & 0.837 \\
\hline & FC3 & 0.865 & & \\
\hline \multicolumn{5}{|c|}{ Learners' autonomy } \\
\hline & LA1 & 0.842 & 0.666 & 0.857 \\
\hline & LA2 & 0.818 & & \\
\hline & LA3 & 0.788 & & \\
\hline \multicolumn{5}{|l|}{$\begin{array}{l}\text { Performance } \\
\text { expectancy }\end{array}$} \\
\hline & PE2 & 0.773 & 0.604 & 0.82 \\
\hline & PE3 & 0.814 & & \\
\hline & $\mathrm{PE} 4$ & 0.743 & & \\
\hline \multicolumn{5}{|c|}{ Social influence } \\
\hline & SI2 & 0.786 & 0.597 & 0.816 \\
\hline & SI3 & 0.759 & & \\
\hline & $\mathrm{SI} 4$ & 0.773 & & \\
\hline
\end{tabular}

We assessed discriminant validity following Fornell and Larcker (1981), who compare the AVE with squared correlations or alternatively compare the square root of the AVE with the correlations. As shown in Table 4, the square roots of the AVE (bolded) are all higher than the off-diagonal correlation values, suggesting that there is sufficient discriminant validity. Thus, we can conclude that the measures used in this study show appropriate validity and reliability. 
Table 4

Discriminant Validity of Measurement Model

\begin{tabular}{|c|c|c|c|c|c|c|c|}
\hline & 1 & 2 & 3 & 4 & 5 & 6 & 7 \\
\hline 1. Effort expectancy & 0.766 & & & & & & \\
\hline 2. Facilitating conditions & 0.573 & 0.848 & & & & & \\
\hline 3. Social influence & 0.538 & 0.527 & 0.773 & & & & \\
\hline 4. Performance expectancy & 0.484 & 0.454 & 0.455 & $\mathbf{0 . 7 7 7}$ & & & \\
\hline 5. Learners' autonomy & 0.472 & 0.47 & 0.415 & 0.466 & $\mathbf{0 . 8 1 6}$ & & \\
\hline 6. Behavioral intention & 0.417 & 0.473 & 0.448 & 0.455 & 0.704 & $\mathbf{0 . 7 8 8}$ & \\
\hline 7. Content quality design & 0.53 & 0.621 & 0.601 & 0.528 & 0.555 & 0.558 & 0.734 \\
\hline
\end{tabular}

\section{Structural Model}

Next step was to test the hypotheses developed for this study by running a bootstrapping procedure with a resample of 5000, as suggested by Hair et al. (2014). The results are presented in Table 5 . The $\mathrm{R}^{2}$ for performance expectancy was 0.278 , effort expectancy was 0.281 , and behavioural intention was 0.541 , which were all acceptable based on the cut-off suggested by Cohen (1988). Content quality design $(\beta=$ $0.528, \mathrm{p}<0.01$ ) was positively related to performance expectancy. Additionally, content quality design ( $\beta$ $=0.53, \mathrm{p}<0.01$ ) was positively related to effort expectancy. Next, we examined the predictors of behavioural intention and found learners' autonomy $(\beta=0.568, \mathrm{p}<0.01)$, performance expectancy $(\beta=$ 0.097, $\mathrm{p}<0.05$ ), social influence $(\beta=0.125, \mathrm{p}<0.05)$, and facilitating conditions $(\beta=0.114, \mathrm{p}<0.05)$ had a positive effect on behavioural intention to use m-learning. However, effort expectancy $(\beta=-0.03, p>$ o.10) had no direct significant effects on intention to use mobile learning.

Table 5

Discriminant Validity of Measurement Model

\begin{tabular}{|l|l|l|l|l|l|l|l|l|l|}
\hline Hypo & Relationship & $\begin{array}{l}\text { Std. } \\
\text { beta }\end{array}$ & Std. error & t-value & $\begin{array}{c}\text { P } \\
\text { values }\end{array}$ & Decision & $\mathrm{R}^{2}$ & $\mathrm{~F}^{2}$ & $\mathrm{Q}^{2}$ \\
\hline H1 & PE -> BI & 0.097 & 0.052 & $1.842^{*}$ & 0.033 & Supported & 0.541 & 0.013 & 0.310 \\
\hline H2 & EE -> BI & -0.03 & 0.063 & 0.062 & 0.486 & $\begin{array}{c}\text { Not } \\
\text { Supported }\end{array}$ & & 0.001 & \\
\hline H3 & SI -> BI & 0.125 & 0.06 & $2.067^{*}$ & 0.019 & Supported & & 0.021 & \\
\hline H4 & FC -> BI & 0.114 & 0.06 & $1.909^{*}$ & 0.028 & Supported & & 0.016 & \\
\hline H5 & LA -> BI & 0.568 & 0.06 & $9.431^{* *}$ & 0.000 & Supported & & 0.467 & \\
\hline H6 & CQD -> PE & 0.528 & 0.043 & $12.292^{* *}$ & 0.000 & Supported & 0.278 & 0.386 & 0.158 \\
\hline $\begin{array}{l}\text { H7 } \\
\text { CQD -> EE }\end{array}$ & 0.53 & 0.042 & $12.765^{* *}$ & 0.000 & Supported & 0.281 & 0.390 & 0.155 \\
\hline
\end{tabular}


As suggested by Cohen (1988), the effect sizes ( $\left.\mathrm{f}^{2}\right)$ for learners' autonomy and content quality design are large, while social influence has small effect size. effort expectancy, performance expectancy, and facilitating conditions have weak effect size. The $\mathrm{Q}^{2}$ values were all greater than zero, which suggests that there is predictive relevance (Hair et al., 2014; Fornell \& Cha, 1994).

Finally, Tenenhaus, Vinzi, Chatelin, and Lauro (2005) recently developed a goodness of fit (GoF) for PLS; in our model, the GoF is 0.478 , which indicates a good fit. The final research model with explained variance and path coefficients is shown in Figure 1.

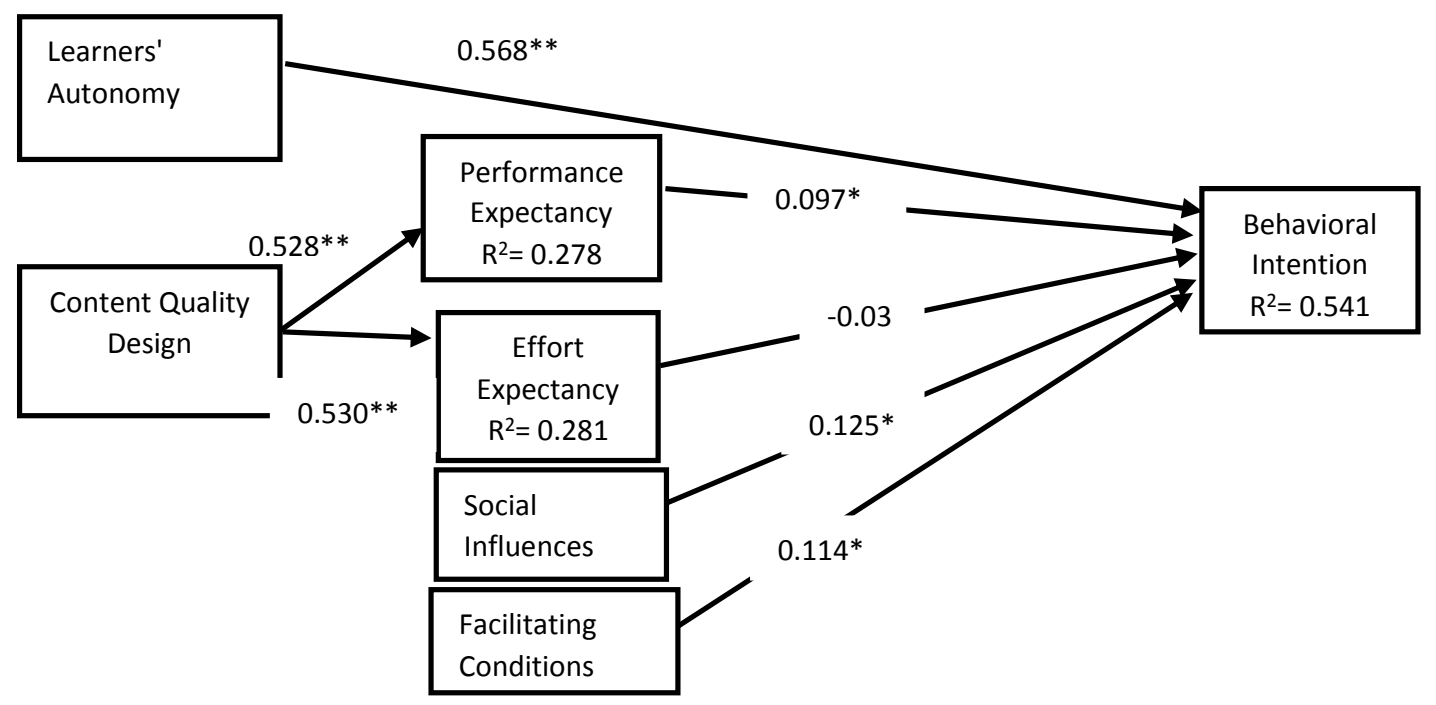

Figure 1. Testing result of the final model.

Note. ${ }^{*} \mathrm{P}<0.05,{ }^{* *} \mathrm{P}<0.01$.

\section{Discussion}

The discussion section presents the results obtained from the empirical survey. The results show that all of the hypotheses are significant except the relation between effort expectancy and behavioural intention. Subsequently, we will discuss the importance of each factor observed in the data. The study found that H6 and $\mathrm{H}_{7}$ were significant; therefore, content quality design affected both effort expectancy and performance expectancy of m-learning. This result was consistent with the study of Almaiah et al. (2016) that found content quality design has a positive effect on perceived usefulness and perceived ease of use of mobile learning applications. The relationship between learners' autonomy and behavioural intention is strongly significant; therefore, $\mathrm{H}_{5}$ is supported. This result is aligned with the previous findings of Liaw, Huang, and Chen (2007) in the context of e-learning. Among all constructs, learners' autonomy was found to have a greater effect size, with $\mathrm{f}^{2}=0.467$. Interestingly, learners' autonomy has the highest path-coefficient with behavioural intention to use m-learning, which causes us to conclude that the learners' autonomy has a strong significant effect on behavioural intention to use m-learning. Higher levels of autonomy allow increasing the intention of the learners to use m-learning. In this study, performance expectancy (perceived 
usefulness) was found to be significant on intention to use m- learning that corresponds with what Abu-AlAish and Love (2013), Chang, 2013, Jambulingam, 2013, and Nassuora (2012) found in the context of mlearning. Therefore, $\mathrm{H} 1$ is supported with $\beta$ value 0.097 . The $\mathrm{P}$-value for effort expectancy (perceived ease of use) is 0.486 , which is far greater than 0.05 at $95 \%$ significant level. Therefore, the H2 is not supported and effort expectancy is deemed as an insignificant factor in this study. It is believed that the reason being is the lack of user-friendliness and comfortable design of the system. Maniar, Bennett, Hand, and Allan (2008) claimed that several possible technological restrictions may hinder m-learning adoption, such as the quality of the screen (screen resolution) and the size of the screen. Kukulska-Hulme (2007) identified that some of the devices are not suitable for educational use of m-learning activity and that usability issues are also highly reported by the users. Park, Nam, and Cha (2012) developed a study on university students' behavioural intention towards the use of mobile learning and also agreed that perceived ease of use and perceived usefulness did not have any significant effects on students' intentions towards the use of mobile learning. Social Influence is considered to have a positive effect that can increase the intention of the learners to use m-learning. Therefore, $\mathrm{H}_{3}$ is supported. This result was consistent with Abu-Al-Aish and Love (2013), Al-Hujran et al. (2014), Jairak et al. (2009), and Wang et al. (2009) in the context of mlearning. Facilitating conditions was found to be significant on intention to use m-learning; accordingly, $\mathrm{H}_{4}$ is supported. This result is aligned with the previous findings of Attalla et al. (2012), Iqbal and Qureshi (2012), and Jairak et al. (2009).

\section{Conclusion and Implications}

This research paper provides an insight on the factors influencing intention to use mobile learning in Egypt. Additionally, this research assists m-learning applications developer to understand the factors that influence intention to use of m-learning apps by Egyptian students. Learners' autonomy is very crucial for increasing the intention of the learners to use m-learning. Therefore, if companies or schools want to develop m-learning apps, they should first concentrate on increasing the learners' autonomy elements such as exams and quizzes. Content quality design positively affected effort expectancy and performance expectancy of m-learning. Content quality design can be realized by providing students with up-to-date content with the effects of multimedia such as audio, video, and animation content. Performance expectation has a high impact on intention to use m-learning. Mobile learning designers have to design mobile learning applications that improve students' performance, such as design applications that are faster in browsing and downloading. Social influence has a positive impact on behavior intention to use mobile learning. To enhance the social influence, teachers and parents should recommend using mobile devices in study lessons and assignments as an effective way that is consistent with today's rapid development of technology. Additionally, facilitating conditions has a positive impact on behavior intention to use mobile learning and can be realized by providing learners with mobile devices, networks, and new and useful applications that can lead them to production and innovation. 


\section{Future Work}

The findings of this research have been discussed and directions for future studies will be also proposed. Firstly, future study may include actual use behaviour or other external variables that will potentially influence students' behavioural intentions on mobile learning. Secondly, the study investigated public preparatory school levels in Egypt. It was suggested that the inclusion of secondary schools or primary schools in private or public schools would be beneficial. Thirdly, the study would be more effective if it included the parents' behavioural intentions toward their children using mobile learning.

\section{Acknowledgements}

This research is supported by USM fellowship from Institute of Postgraduate Studies (IPS) in Universiti Sains Malaysia (USM). The authors would like to thank the School of Computer Science for providing the facilities for this research. 


\section{References}

Abu-Al-Aish, A., \& Love, S. (2013). Factors influencing students' acceptance of m-learning: An investigation in higher education. The International Review of Research in Open and Distributed Learning, 14(5), 82-107.

Al-Hujran, O., Al-Lozi, E., \& Al-Debei, M. M. (2014). Get ready to mobile learning: Examining factors affecting college students' behavioral intentions to use m-learning in Saudi Arabia. Journal of Business Administration, 1O(1), 111-128.

Ali, R. A., \& Arshad, M. R. M. (2016). Perspectives of students' behavior towards mobile learning (mlearning) in Egypt: an extension of the UTAUT model. Engineering, Technology \& Applied Science Research, 6(4), 1109-1114.

Almaiah, M. A., Jalil, M. A., \& Man, M. (2016). Extending the TAM to examine the effects of quality features on mobile learning acceptance. Journal of Computers in Education, 3(4), 453-485.

Alshalabi, I. A., \& Elleithy, K. (2012). Effective m-learning design strategies for computer science and engineering courses. International Journal of Mobile Network Communications \& Telematics (IJMNCT), 2(1), 1-11. doi: 10.5121/ijmnct.2012.2101

Alzahrani, A., Stahl, B. C., \& Prior, M. (2012). Developing an instrument for e-public services' acceptance using confirmatory factor analysis: Middle East context. Journal of Organizational and End User Computing (JOEUC), 24(3), 18-44.

Anderson, J. C., \& Gerbing, D. W. (1988). Structural equation modeling in practice: A review and recommended two-step approach. Psychological Bulletin, 103(3), 411.

Attalla, S. M. E.-S., El-Sherbiny, R., Mokbel, W. A., El-Moursy, R. M., \& Abdel-Wahab, A. G. (2012). Screening of students' intentions to adopt mobile-learning: A case from Egypt. International Journal of Online Pedagogy and Course Design (IJOPCD), 2(1), 65-82.

Badwelan, A., Drew, S., \& Bahaddad, A. A. (2016). Towards acceptance m-learning approach in higher education in Saudi Arabia. International Journal of Business and Management, 11(8), 12.

Bere, A. (2014). Exploring determinants for mobile learning user acceptance and use: an application of UTAUT. Paper presented at the ITNG 2014, 11th International Conference on Information Technology: New Generations, Las Vegas, Nevada, USA: IEEE Computer Society.

Bidin, S., \& Ziden, A. A. (2013). Adoption and application of mobile learning in the education industry. Procedia-Social and Behavioral Sciences, 90, 720-729.

Chang, C.-C. (2013). Library mobile applications in university libraries. Library Hi Tech, 31(3), 478-492. 
Chung, H.-H., Chen, S.-C., \& Kuo, M.-H. (2015). A study of EFL college students' acceptance of mobile learning. Procedia-Social and Behavioral Sciences, 176, 333-339.

Cohen, J. (1988). Statistical power analysis for the behavioral sciences ( $2^{\text {nd }}$ ed.): New York: Academic Press

Coursaris, C., \& Hassanein, K. (2002). Understanding m-commerce: a consumer-centric model. Quarterly Journal of Electronic Commerce, 3, 247-272.

Davis, F. D. (1989). Perceived usefulness, perceived ease of use, and user acceptance of information technology. MIS Quarterly, 13(3) 319-340.

Dyson, L. E., Litchfield, A., Raban, R., \& Tyler, J. (2009). Interactive classroom mLearning and the experiential transactions between students and lecturer. Paper presented at the Proceedings of Ascilite, Auckland.

Hair Jr., J., Sarstedt, M., Hopkins, L., \& G. Kuppelwieser, V. (2014). Partial least squares structural equation modeling (PLS-SEM) An emerging tool in business research. European Business Review, 26(2), 106-121.

Fornell, C., \& Cha, J. (1994). Partial least squares. In R. P. Bagozzi (Ed.), Advanced methods of marketing research (pp. 52-78). Cambridge, MA: Blackwell.

Fornell, C., \& Larcker, D. F. (1981). Evaluating structural equation models with unobservable variables and measurement error. Journal of Marketing Research, 13, 39-50.

Brantes Ferreira, J., Zanela Klein, A., Freitas, A., \& Schlemmer, E. (2013). Mobile learning: Definition, uses and challenges In Increasing student engagement and retention using mobile applications: smartphones, skype and texting technologies (pp. 47-82). Emerald Group Publishing Limited.

Galal, R. (2016). How Egypt plans to build its next generation of scientists. Retrieved from http://www.almonitor.com

GSM Association and NTT DOCOMO. (2014) . Children's use of mobile - an international comparison 2013. Japan. Retrieved from https://www.gsma.com/publicpolicy/wpcontent/uploads/2012/03/GSMA ChildrensMobilePhones2013WEB.pdf

Hwang, G. J., \& Tsai, C. C. (2011). Research trends in mobile and ubiquitous learning: A review of publications in selected journals from 2001 to 2010. British Journal of Educational Technology, 42(4), E65-E70. 
Ibrahim, R., \& Jaafar, A. (2011). User acceptance of educational games: A revised unified theory of acceptance and use of technology (UTAUT). World Academy of Science, Engineering and Technology, 77, 557-563.

Iqbal, S., \& Qureshi, I. A. (2012). M-learning adoption: A perspective from a developing country. The International Review of Research in Open and Distributed Learning, 13(3), 147-164.

Jairak, K., Praneetpolgrang, P., \& Mekhabunchakij, K. (2009). An acceptance of mobile learning for higher education students in Thailand. Paper presented at the Sixth International Conference on eLearning for Knowledge-Based Society, Thailand.

Jambulingam, M. (2013). Behavioural intention to adopt mobile technology among tertiary students. World Applied Sciences Journal, 22(9), 1262-1271.

Jawad, H., \& Hassan, Z. (2015). Applying UTAUT to evaluate the acceptance of mobile learning in higher education in Iraq. International Journal of Science and Research (IJSR), 4(5), 952-954.

Jeong, H.-Y., \& Hong, B.-H. (2013). A practical use of learning system using user preference in ubiquitous computing environment. Multimedia Tools and Applications, 64(2), 491-504.

Krejcie, R. V., \& Morgan, D. W. (1970). Determining sample size for research activities. Educational and Psychological Measurement, 3o(3), 607-610.

Kuciapski, M. (2016). Students acceptance of m-learning for higher education-UTAUT model validation. Paper presented at the EuroSymposium on Systems Analysis and Design.

Kukulska-Hulme, A. (2007). Mobile usability in educational contexts: what have we learnt? The International Review of Research in Open and Distributed Learning, 8(2).

Kuo, Y.-C., Walker, A. E., Schroder, K. E., \& Belland, B. R. (2014). Interaction, internet self-efficacy, and self-regulated learning as predictors of student satisfaction in online education courses. The Internet and Higher Education, 20, 35-50.

Lee, Y., \& Kozar, K. A. (2006). Investigating the effect of website quality on e-business success: An analytic hierarchy process (AHP) approach. Decision Support Systems, 42(3), 1383-1401.

Liaw, S.-S., Hatala, M., \& Huang, H.-M. (2010). Investigating acceptance toward mobile learning to assist individual knowledge management: Based on activity theory approach. Computers \& Education, 54(2), 446-454.

Liaw, S.-S., Huang, H.-M., \& Chen, G.-D. (2007). Surveying instructor and learner attitudes toward elearning. Computers \& Education, 49(4), 1066-1080. 
Liu, Y. (2011). Solving the puzzle of mobile learning adoption (Doctoral dissertation), Åbo Akademi University. Retrieved from https://www.doria.fi/bitstream/handle/10024/69575/liu_yong.pdf?sequence=1

Liu, Y., Han, S., \& Li, H. (2010). Understanding the factors driving m-learning adoption: A literature review. Campus-Wide Information Systems, 27(4), 210-226.

Makoe, M. (2010). Linking mobile learning to the student-centred approach (Blog post). Retrieved from http://www.checkpoint-elearning.com/article/8044.html

Maniar, N., Bennett, E., Hand, S., \& Allan, G. (2008). The effect of mobile phone screen size on videobased learning. Journal of Software , 3(4), 51-61.

Martin, F., \& Ertzberger, J. (2013). Here and now mobile learning: An experimental study on the use of mobile technology. Computers \& Education, 68, 76-85.

Nassuora, A. B. (2012). Students acceptance of mobile learning for higher education in Saudi Arabia. American Academic \& Scholarly Research Journal, 4(2), 24-30.

Ng, K. S., Ibrahim, M. A., Ahmad, A. R., \& Ng, M. X. S. (2015). Factors influencing intention to use mobile technologies for learning among technical universities students. Paper presented at the 26th IBIMA Conference. Innovation and Sustainable Economic Competitive Advantage: From Regional Development to Global Growth, Madrid, Spain.

Park, S. Y., Nam, M. W., \& Cha, S. B. (2012). University students' behavioral intention to use mobile learning: Evaluating the technology acceptance model. British Journal of Educational Technology, 43(4), 592-605.

Ramayah, T., Lee, J. W. C., \& In, J. B. C. (2011). Network collaboration and performance in the tourism sector. Service Business, 5(4), 411.

Ringle, C. M., Wende, S., \& Becker, J.-M. (2015). SmartPLS 3. Boenningstedt: SmartPLS GmbH

Selfe, C. L. (1999). Technology and literacy in the 21st century: The importance of paying attention. Carbondale, IL: SIU Press.

Sheppard, B. H., Hartwick, J., \& Warshaw, P. R. (1988). The theory of reasoned action: A meta-analysis of past research with recommendations for modifications and future research. Journal of Consumer Research, 15(3), 325-343.

Sureephong, P., Sirichai, P., \& Winya, S. (2015). Technology Acceptance of Thai Primary Student on Outdoor Learning Activity Using Mobile Device. Subconscious Learning via Games and Social Media Gaming Media and Social Effects, 101-113. doi:10.1007/978-981-287-408-5_8 
Tenenhaus, M., Vinzi, V. E., Chatelin, Y.-M., \& Lauro, C. (2005). PLS path modeling. Computational Statistics \& Data Analysis, 48(1), 159-205.

Venkatesh, V., \& Davis, F. D. (2000). A theoretical extension of the technology acceptance model: Four longitudinal field studies. Management Science, 46(2), 186-204.

Venkatesh, V., Morris, M. G., Davis, G. B., \& Davis, F. D. (2003). User acceptance of information technology: Toward a unified view. MIS Quarterly, 27(3), 425-478.

Viberg, O., \& Grönlund, Å. (2013). Cross-cultural analysis of users' attitudes toward the use of mobile devices in second and foreign language learning in higher education: A case from Sweden and China. Computers \& Education, 69, 169-180.

Wang, Y. S., Wu, M. C., \& Wang, H. Y. (2009). Investigating the determinants and age and gender differences in the acceptance of mobile learning. British Journal of Educational Technology, 4O(1), 92-118.

Watts, N. (1997). A Learner-based approach to computer mediated language learning. System, 25(1), 1-8.

West, D. M. (2013). Mobile learning: Transforming education, engaging students, and improving outcomes. Washington, DC: Center for Technology Innovation at Brookings.

Winters, N. (2007). What is mobile learning. In M. Sharples (Ed.), Big issues in mobile learning (pp. 711). University of Nottingham.

Yeap, J. A., Ramayah, T., \& Soto-Acosta, P. (2016). Factors propelling the adoption of m-learning among students in higher education. Electronic Markets, 26(4), 323-338.

\section{Athabasca University}

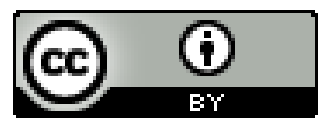

